\title{
MRS Headquarters Expands Services to Membership
}

\author{
Seven Staff Members Prepare for 1986 Society Activities
}

In sightly over two years, the Materials Research Society has grown from an organization with a membership of 1,500 to a joint member/professional staff operated Society which offers services such as two international annual meetings, an equipment exhibit, 50 proceedings volumes, extensive short course program, and an archival journal. The membership now exceeds 3,500 world wide and supports the activities of similar materials research groups in Europe, Asia, Australia and elsewhere.

Since the appointment of John B. Ballance as executive director for the Society in October 1983, six additional people have joined the staff with special skills to enable the Officers, Councillors, and members to rapidly implement many of the new activities reported during the past year.

We invite you to become acquainted with the MRS staff members and contact them to convey your ideas or to volunteer your expertise to enhance MRS's current membership activities. If you are attending the Fall Meeting in Boston, look for staff members in the Registration area and introduce yourself

\section{John B. Ballance, Executive Director}

John Ballance is responsible for both the financial and philosophical success of the Materials Research Society. Under his direction over the past two years, MRS has computerized the membership records, consolidated targeted promotion of meetings and short courses, and successfully implemented a second annual MRS meeting held every Spring, an equipment exhibit, a short course program, and in-house publishing of conference proceedings and the MRS BULLETIN. His emphasis on membership promotion and intersociety relations has resulted in increased international visibility for the Society and growth in membership by more than $100 \%$. John holds bachelors and masters degrees in metallurgy from North Carolina State University. He has worked with light-weight steels at Republic Steel Corporation and beryllium-copper alloys at Brush-Wellman. Prior to joining MRS, he was editor of Journal of Metals and director of publications for the Metallurgical Society of AIME.

\section{Gail A. Oare, Director of Publications}

Gail joined MRS in 1984 with responsibility for proceedings production, marketing, and fulfillment, and BULLETIN editorial, production, and advertising. She now is also working on the startup of journal of

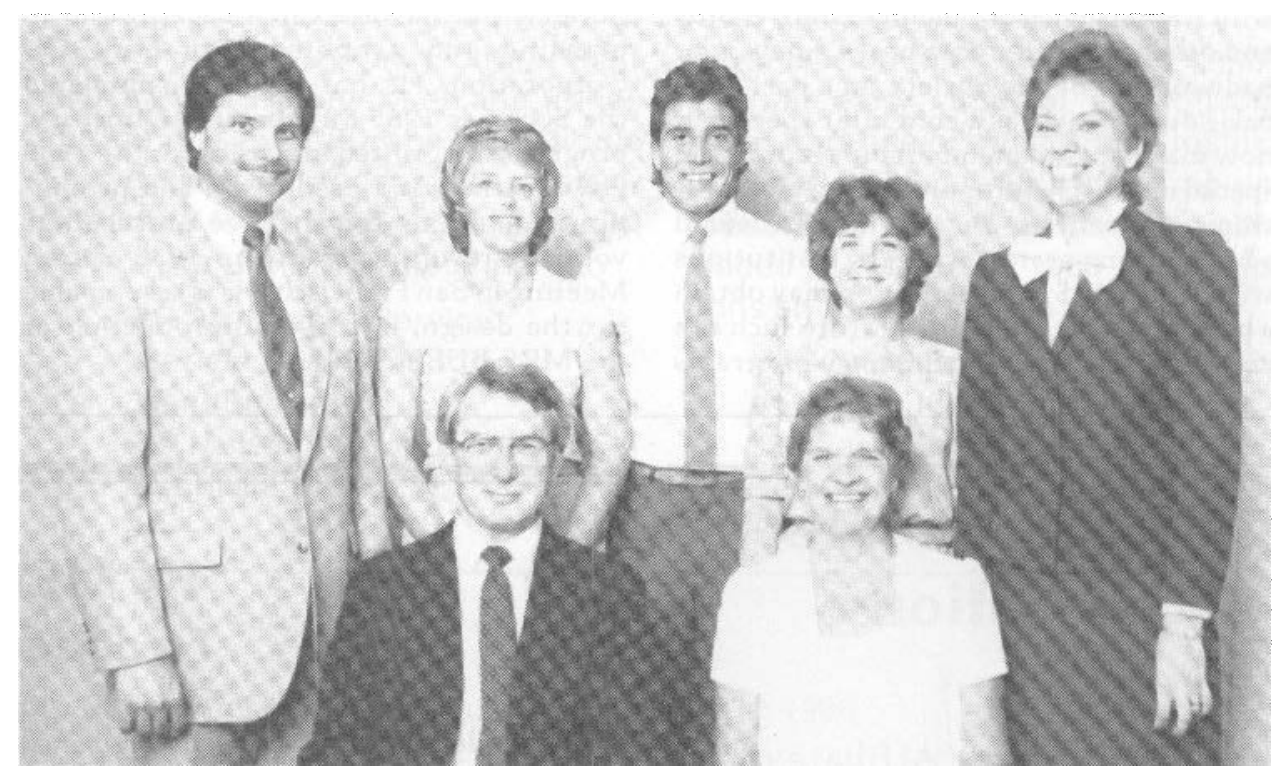

MRS staff (left to right) bottom row: John Ballance, Anne Wagner. Top row: Mike Alberty, Mary Kaufold, Pat Gruden, Gail Oare, Lucy Blackford.

Materials Research through the American Institu te of Physics. Since November 1984, MRS has published 15 books in-house and plans are underway for the completion of 26 more books by Fall 1986. Gail has over 10 years of experience in editorial, production, and marketing of technical and educational books, journals, and films. She has worked in the publications departments of the Instrument Society of America, Development Dimensions International, and was managing editor of Journal of Metals and director of periodical publications for The Metallurgical Society of AIME prior to joining MRS

\section{Michael C. Alberty, Director of Member Services}

Mike joined the staff in July 1985 in this major new position within Headquarters established to foster growth of the Society's annual meetings in the Spring and Fall. In conjunction with this activity, Mike coordinates equipment exhibits, and job placement centers with the American Institute of Physics and works with short course program manager Vivienne Harwood Mattox to promote and implement MRS short courses. Mike, who is working on his doctorate in communications and technology at the University of Pittsburgh and previously worked for Copperweld Corporation as project manager of information systems, is also responsible for computer hardware and software implementation in member records, accounting, and publications.

\section{Mary E. Kaufold, Accounting and Publications Orders}

Mary has worked for MRS on a parttime basis since November 1984 and joined the staff full time in July. She brings to MRS experience in commercial banking and is responsible for general Society accounting and financial records. She handles proceedings and reprint orders and oversees fulfillment of these areas. She is currently working to bring on-line a new accounting software package to permit more efficient recordkeeping for MRS finances. Mary is also responsible for symposium funding activities.

\section{Anne Wagner, Administrative Assistant to Executive Director}

Anne Wagner was the second person to join the staff of MRS. She began working with John Ballance in November 1983, responsible at that time for overseeing and implementing meeting registration, membership promotion, and proceedings order fulfillment. Anne now serves as office manager and assists John in general Society operations. She coordinates short course and meeting registration and membership mailings, and provides support to MRS

(continued on next page) 
corporate affiliates and MRS symposia chairs. Anne was secretary to the director of publications for the Instrument Society of America from 1973-1980 and then secretary in the Purchasing Department of Joy Manufacturing Company until she joined MRS two years ago.

\section{Lucy Blackford, Membership Records}

In January 1985, Lucy joined the staff with responsibility for membership records and other computer data bases. Lucy, who had worked for the Society on a part-time basis during 1984 as a computer specialist, now main tains all membership records and special interest lists for promoting membership and meetings. She recently instituted a bulk mailing system whereby institutions with large MRS representation may obtain a bulk shipment of MRS literature such as a calls for papers and preliminary programs for speedier internal distribution. Anyone interested in using this service is encouraged to contact her for details.

\section{Patrick M. Gruden, Graphic Artist}

Pat joined the staff in June 1985 to handle design and production of proceedings, abstract books, and general promotional and meetings materials for the Society. Pat has a diverse background in printing and graphics with Gulf Oil Corporation. He has recently completed the Society's 1985 Membership Directory, program and printed materials for the 1985 Fall Meeting, and production and promotional materials for the five proceedings volumes resulting from the 1985 Spring Meeting in San Francisco. He is responsible for the design, layout, and production of the MRS BULLETIN.
"MRS is at a critical stage of growth," according to John Ballance, "and the expertise provided by the staff will enable us to refine administration of current member services and to implement new innovations." In addition to the new Journal of Materials Research, and expansion of book publishing, meetings, and short course and corporate participation programs, MRS is experiencing significant activity on the local and international levels, according to Ballance. New Sections, Student Chapters, and MRS groups in Europe, Asia, Australia, and elsewhere will require support from Headquarters in the coming year.

"We are enthusiastic about the new activities planned for 1986, " he said, "and invite the members to contact the Headquarters staff to discuss their ideas on any of thicse programs."
MRS Corporate

Participation

\section{Program}

As a Corporate Affiliate of the Materials Research

Society, your organization is kept abreast of the Society's goals and activities and afforded special

opportunities to enhance your research programs through:

\section{- Subscription to MRS} BULLETIN

- Advance notification of meeting programs and events

- Discounts on symposia proceedings

- Free employment ad placement in MRS BULLETIN

And more.

For complete details on the program, contact MRS Headquarters, 9800 McKnight Road, Suite 327, Pittsburgh, PA 15237; (412) 367-3003

\section{IN MEMORIUM Frederick $W$. Vratny}

Frederick W. Vratny, a Distinguished Member of the Technical Staff at A T\& T Bell Laboratories, died September 4, 1985 after a prolonged illness.

Fred Vratnyearned the BS degree in chemistry in 1953 from the University of Michigan where he was a Regents Scholar. He was awarded the MS and PhD degrees in physical chemistry in 1956 from the University of Indiana, where he authored a thesis on the analytical aspects of Raman spectroscopy. Prior to joining Bell Laboratories, Vratny spent four years as a Professor of Physics and Chemistry at Purdue University.

Fred Vratny joined Bell Laboratories in 1960. His early work was devoted to the study of thin films for circuits and discrete devices. He also contributed to the understanding of conduction in thin dielectrics and applied this knowledge to the invention of novel switching devices and varactors. Vratny next contributed extensively to the technology and metallurgy of tantalum, tantalum oxide and tantalum nitride thin films and their application in thin film circuitry. He pioneered in understanding the sputter deposition and etching of these materials, and much of the insight gained in this period was crucial to the successful manufacture of thin film circuits.

Following his work in thin film circuit technology, Vratny became involved in the development of materials and processes for integrated circuit fabrication, where he contributed significantly. He studied photoresist materials, cleaning processes, and the source and nature of VLSI circuit defects. He brought to his work in this field the highest level of scientific curiosity and thoroughness, and consequently established the basic understanding required for sound engineering of processes and equipment. Vratny also contributed to the development of $x$-ray lithographic technology by studying the materials and fabrication processes required to form $x$-ray masks.

Finally, Vratny followed his interests in integrated circuit technology to the field of packaging, where he produced inventive solutions to the packaging problems posed by modern VLSI circuitry. His work in this area again focused upon materials and processes required for the solution of practical problems. In all, Vratny was awarded 18 patents for inventions in sputtering technology, plating, imaging devices, $x$-ray lithography, and device fabrication. A like number of patent applications remained pending at the time of his death.

Fred Vratny was a dedicated, generous colleague whose presence at Bell Laboratories will be missed 